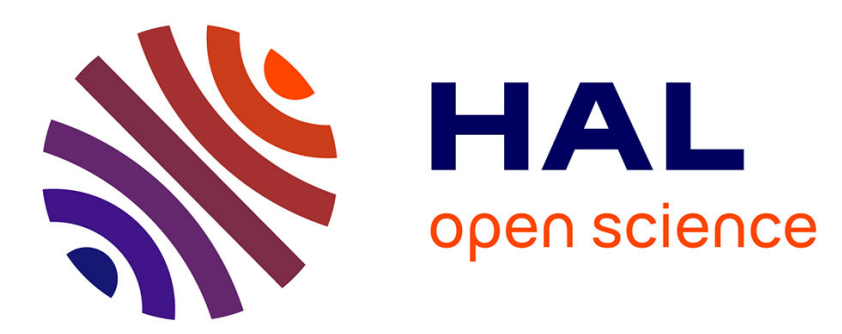

\title{
How French managers picture their careers: a gendered perspective
}

Christine Naschberger, Krista Finstad-Milion

\section{To cite this version:}

Christine Naschberger, Krista Finstad-Milion. How French managers picture their careers: a gendered perspective. Equality, Diversity and Inclusion: An International Journal, 2017, 36 (5), pp.401 - 416. 10.1108/EDI-10-2016-0082 . hal-01586621

\section{HAL Id: hal-01586621 \\ https://hal-audencia.archives-ouvertes.fr/hal-01586621}

Submitted on 13 Sep 2017

HAL is a multi-disciplinary open access archive for the deposit and dissemination of scientific research documents, whether they are published or not. The documents may come from teaching and research institutions in France or abroad, or from public or private research centers.
L'archive ouverte pluridisciplinaire HAL, est destinée au dépôt et à la diffusion de documents scientifiques de niveau recherche, publiés ou non, émanant des établissements d'enseignement et de recherche français ou étrangers, des laboratoires publics ou privés. 


\title{
How French managers picture their careers: A gendered perspective
}

\author{
Christine Naschberger, Audencia Business School \\ Krista Finstad-Milion, ICN Business School
}

\begin{abstract}
Purpose: This paper investigates how French managers picture their careers, specifically female careers.

Design/methodology/approach: The sample was composed of 93 women and 5 men attending a professional women's networking event in France. Participants answered a questionnaire, including images to choose from to best describe how they perceived their own career development.
\end{abstract}

Findings: The results indicate that a female career is closely associated with work-life balance by both women and men. Also, women acknowledge three times more than men, the existence of a glass ceiling in their organisation Women and men choose both traditional and contemporary images of career.

Research limitations/implications: As the sample was taken from a women's network event, the male sample size is small. Despite the small sample of men, giving voice to male participants leads to rich insights which challenge gendered and non-gendered career models.

Practical implications: On an individual level, reflection on one's career path fosters awareness and ownership of career choices. Further, working with career images enhances discussion and experience-sharing about personal career choices, and offers opportunities to organisations concerned with developing female talent.

Originality/value: The study contributes to the career literature by providing insights into how female and male managers perceive female careers. The study's originality lies in the methodology, based on using images of careers to better understand how managers picture their own careers.

Key words: managers, women, careers, career development, perceptions, images, France 


\section{Introduction}

This paper contributes to the individualist stream of career research (Baruch, 2004), aiming to shed light on how women perceive their own careers. It also responds to the call for more research on women's careers (White, 1995, 2000; Belghiti-Mahut, 2004; Laufer, 2004), the need to develop new perspectives on careers and career development (Arthur et al., 1989; Inkson and Amundson, 2002; Baruch, 2003), including national perspectives (Cadin et al., 2000; Herman et al., 2013), and the call to investigate the necessity for gender-distinct career theories (Wilson, 1998; O’Neil and Bilimoria, 2005; O’Neil et al., 2005, 2008; Dyke and Murphy, 2006; Eikhof, 2012). Such calls for research seek to meet the expectations of managers, women and men alike, with respect to career choices made through the course of one's life (Hakim, 2000). The study is also in keeping with legislation driven by the French government to encourage greater female/male professional equality in the workplace (Vinquant, 2017)

Finally, the study addresses the growing interest in capturing careers by way of dominant pictures or metaphors (Baruch, 2004; Kram et al., 2012) and especially those of women (Eagly and Carli, 2007; Naschberger et al., 2012). Although images are prevalent in the existing gendered career literature, they are largely used to capture invisible or ordinary obstacles to women's careers, rather than to serve as a means of better understanding individual careers, promoting opportunities and moving forward. In the career literature, images serve as references for discussion of careers which are considered complex social constructs. Investigating career images and their multiple interpretations helps to reveal layers of meaning which words cannot capture by themselves.

In order to respond to individual managers' concerns and methodological orientations with regard to careers, a review of the relevant literature was carried out. The approach taken in this paper is innovative, as images commonly discussed in the literature are used for a field study. An empirical study on how managers picture their careers, as well as women's careers 
in particular, was conducted during a French women's networking event. The 93 female and 5 male manager respondents were of different ages and performed different functions, representing a wide range of business sectors. The perceptions managers have of their careers were analysed with the aim of identifying several dominant images and understanding the career interpretations such images give way to.

\section{Review of the career literature}

A review of the career literature traces the movement from more rigid to more flexible career development models as well as the growing attention paid to gendered career models.

\section{From rigid to more flexible career development models}

Research on careers and career development has traditionally been based on a linear model of progress in a firm, with a focus on access to positions with higher status, prestige, levels of responsibility, and salaries (Williams, 2000). One of the most cited career development stage models was developed by Super (1957), who identified several career stages through the life course: trial, establishment, maintenance, and decline. Later, Levinson (1978) elaborated a model of life development: a comprehensive eight-phase model associated with one's biological age. The previously cited models and early work on career stages resulted from studies on men. Moreover, the traditional approach to career advancement is a normative one (Pralong, 2009); there is one way to climb the career ladder: working in a given position enables the employee to move on to the next given post. According to the normative approach, career pathways are institutionalised, which is still the case in many large firms. However, changing employee expectations and less predictable organisational trajectories are challenging traditional ways of looking at careers, career patterns, and decision-making about careers, and have led, more recently, to alternative career development models.

Indeed, shifts in the meaning and understanding of career and advancement have occurred in the past two decades. The emerging forms of career have been given intriguing labels, such as 
boundaryless (Nicholson, 1996), protean (Hall and Mirvis, 1996), nomad (Cadin et al., 2000), spiral (Brousseau et al., 1996), cycle (Inkson, 2004), chaotic (Peterson and Anand, 2002), and chronically flexible (Iellatchitch et al., 2003). Although both stable and flexible career perspectives are present in today's organisations, the ways of looking at careers and advancement are being redefined by individuals.

\section{Appearance of gendered career models}

Critical factors make a compelling case for the need to treat women's careers as distinct and worthy of study in their own right (O’Neil and Bilimoria, 2005). Gender-sensitive career studies have given way to gender-distinct career investigation, theory, and models over the past twenty years. Some authors argue that, while women's career advancement challenges have been explored, the concept of career stages as uniquely experienced by women is still not very comprehensive (Yarnall, 2008). Women progress through careers at different rates and with varying succession depending on a number of unique factors such as, for example, family status and family responsibilities (Mayrhofer et al., 2008). Eagly and Carli (2007) find women's decision-making about career development to be contextual and embedded in relationships, an approach which contrasts with the self-driven and more independent decision-making typically associated with traditional career pathways. Female career advancement is interrupted by footrests, periods of stagnation due to pregnancy, motherhood, or other care activities (Yarnall, 2008; Ferro-Vallé, 2009). While males typically enter and exit the career exploration stage during adolescence (Levinson, 1978; Morgan and Foster, 1999), females may experience the career exploration stage for the first time in mid-life, a period when childcare responsibilities decrease (Levinson and Levinson, 1994; Morgan and Foster, 1999). Similarly, the career interruption stage is based on the premise that men have lifelong careers while women may "retire" or intermittently leave the workforce as care obligations arise. The same factors, notably parenthood, an increasing number of children, 
and elderly family members requiring care, have a negative impact on women's career progression, whereas they have a positive impact on that of men (Ferro-Vallé, 2009). Hewlett and Luce (2005) found that women consider temporary exits as a natural evolution of their careers, and that "horizontal” career interruptions are part of a woman's career pathway. However, “coming back" to work and reintegration are considered to be painful and sometimes even impossible, inciting some women to start their own businesses or work as freelancers. It is to be noted that career interruption stages, for women and men alike, largely depend on national labour legislation, such as the existence of maternity, paternity, or parental leave, and the provision of state-subsidised childcare.

The following table presents some of the relevant literature on traditional versus contemporary career development.

\section{Characteristics of traditional and contemporary career pathways}

\begin{tabular}{|c|c|c|}
\hline & Traditional career pathway & Contemporary career pathway \\
\hline Career choice & $\begin{array}{l}\text { Self-driven and independent } \\
\text { (Eagly and Carli, 2007). }\end{array}$ & $\begin{array}{l}\text { Self-driven and dependent on family status } \\
\text { (Mayrhofer et al., 2008) and personality } \\
\text { (Goldberg, 1990). }\end{array}$ \\
\hline Career context & $\begin{array}{l}\text { Prevalence of gender stereotypes } \\
\text { of women as "caregivers" or } \\
\text { "homemakers", and men as } \\
\text { "breadwinners" (Masterson and } \\
\text { Hoobler, 2015). }\end{array}$ & $\begin{array}{l}\text { Consideration for career ambitions of both } \\
\text { spouses (Solomon and Jackson, 2014). } \\
\text { Dual-career couples (Masterson and } \\
\text { Hoobler, 2015). } \\
\text { Appearance of gendered career path. } \\
\text { Relationships with others embedded in } \\
\text { career context (Eagly and Carli, 2007). }\end{array}$ \\
\hline Career aims & $\begin{array}{l}\text { Promotion (Rosenbaum, 1979), } \\
\text { higher status, prestige, levels of } \\
\text { responsibility and salary } \\
\text { (Williams, 2000). }\end{array}$ & $\begin{array}{l}\text { Opportunities for development (Rousseau, } \\
\text { 1996). } \\
\text { Balance between career opportunities and } \\
\text { family life (Levinson and Levinson, 1994; } \\
\text { Mainiero and Sullivan, 2006). } \\
\text { Advancement, fulfilment (Baruch, 2004). }\end{array}$ \\
\hline $\begin{array}{l}\text { Career } \\
\text { exploration stages }\end{array}$ & $\begin{array}{l}\text { Begins at adolescence for men } \\
\text { (Levinson, 1978; Morgan and } \\
\text { Foster, 1999), while may not } \\
\text { begin until mid-life for child- } \\
\text { bearing women (Levinson and }\end{array}$ & $\begin{array}{l}\text { Takes place throughout life at different } \\
\text { life stages (Baruch, 2004). }\end{array}$ \\
\hline
\end{tabular}




\begin{tabular}{|c|c|c|}
\hline & $\begin{array}{l}\text { Levinson, 1994; Morgan and } \\
\text { Foster, 1999). }\end{array}$ & \\
\hline $\begin{array}{l}\text { Nature of } \\
\text { career path }\end{array}$ & $\begin{array}{l}\text { Steady progress through life } \\
\text { events for men (marriage, } \\
\text { children) (Levinson, 1978). } \\
\text { Linear, static, and rigid (Baruch, } \\
\text { 2004). } \\
\text { Includes interruptions for } \\
\text { marriage or caregiving (Levinson } \\
\text { and Levinson, 1994; Yarnall, } \\
\text { 2008; Ferro-Vallé, 2009). } \\
\text { Professional reintegration tends to } \\
\text { be painful (Hewlett and Luce, } \\
\text { 2005). }\end{array}$ & $\begin{array}{l}\text { Multidirectional, fluid, and dynamic } \\
\text { (Baruch, 2004). } \\
\text { Chronically flexible (Iellatchitch et al., } \\
\text { 2003). } \\
\text { Possibility to retreat for a few days to up } \\
\text { to several years depending on state } \\
\text { legislation (maternity, paternity, parental } \\
\text { adoption, care leave) (Scambor et al., } \\
\text { 2013). }\end{array}$ \\
\hline
\end{tabular}

In order to better understand how managers picture their careers, the use of images could be helpful.

\section{Picturing female managers' careers: use of images and metaphors}

Pictures, images, or symbols, as elements of thought, provide a rich source of information about how people make sense of their lives. The use of symbols as career metaphors can capture certain strong feelings, such as frustration or perplexity (Eagly and Carli, 2007). Images are not just descriptors of reality; they reflect cognitive frameworks within which people become clear about their own actions in interaction with others. The work on images can be likened to the work on metaphors, which are in essence images conjured by words or groups of words. Images may even go beyond written or verbal expressions and thereby draw attention to aspects which cannot easily be captured by words. Finally, images help to capture existing complexity, and may reveal layers of unconsciousness. The practice of psychoanalysis is based on a long tradition of using images to put words and feelings on blind spots. White (1995) remarks the predominance of masculine images in career models and the need to conceptualise the careers of successful women over time and space. White aims to capture patterns of adjustment and patterns of issues associated with certain ages and stages in 
life that are characteristic of women. Images are prevalent in the gender and career literature, although largely used to capture invisible or ordinary obstacles or discriminating processes which prevent women from accessing higher-level responsibilities in the workplace: glass ceiling, glass walls, glass cliff, sticky floor, and asbestos are common examples (LandrieuxKartochian, 2003; Laufer, 2004). Of particular interest is the glass ceiling, dating from the 1980s, which we examine here in order to understand to what extent and in what respect this metaphor still offers useful insights for understanding obstacles to career advancement.

A useful starting point for understanding managers' career development is to investigate how they perceive the notion of career and look back over their career history. Common career development images, including the vertical ladder, roller coaster, or more recently the horizontal career ladder, can help individuals explore some of the patterns (Clark, 1996; Bozionelos, 2003). The traditional approach seems to be pervasive in the mountain image, where career advancement is illustrated by ascension achieved: "there is the summit; where all aspire to reach. People climb up as far as they can” (Baruch, 2004, p. 61). Similarly, Baruch observes that, when the career is pictured as a vertical ladder, advancing means moving up the ladder. However, organisations are becoming flatter and increasingly interdependent. In addition individuals today place greater importance on personal development and employability. Horizontal ladder career images offer contemporary alternatives to the vertical ladder. Likewise, the roller coaster image could better represent the increasing instability of organisations and need for greater adaptability of managers.

The labyrinth image represents the career as a myriad of paths through which one has to find a way, as the passage is neither simple nor direct but requires persistence, awareness of one's progress, and a careful analysis of the puzzles that lie ahead (Eagly and Carli, 2007). For Naschberger et al. (2017), this contemporary symbol represents a complex journey towards a goal worth striving for. These authors conclude that the labyrinth is an appropriate image of 
what women are confronted by in their professional endeavours as it acknowledges choices, puzzlement, obstacles, back-tracking and ways out, but ultimately is not as discouraging as other common images of women's career advancement, such as the glass ceiling or sticky floor, tend to be.

In light of our review of the career literature, we aim to explore two main research questions: What can a chosen career image reveal about how female and male managers perceive their career pathway? Do female managers' perceptions of a female career differ from how male managers see female careers?

\section{Methods}

The aim of the present study is to understand individual managers' perceptions of their careers, and in particular those of women, as well as to comprehend how such perceptions correspond to characteristics and images of career development previously discussed in the literature review, as well as shedding light on common assumptions about women's careers. To discover these perceptions, the authors co-moderated an hour-long session built around open questions on careers, during a women's networking event. One of the questions addressed the participants' perceptions of a female career. Another question targeted their perceptions of the existence of the glass ceiling, requesting a qualitative comment to explain their answer. Finally, the participants were asked to choose from one of five career images (see Appendix 1), the image which most resembled their own career. The participants were informed that, if none of the given symbols fit with their career perception, they should draw their own image. In that case, they were asked to provide an explanation.

The authors collected 98 completed questionnaires 110 participants attending the women's network event, signifying a high return rate of $89 \%$. Out of the 98 returned questionnaires, 93 had been completed by women and 5 by men. This paper draws primarily on data from the female managers. However, despite the low number of men attending the event and 
consequently responding to the survey, the paper includes the male respondents' perspectives in the interests of giving voice to male participants, and thereby embracing a gendered approach to the research questions raised about careers.

A research assistant transcribed the participants' responses and the authors coded the responses. To maintain the rich nature of the collected data, the authors used thematic coding for the analysis. Instead of using predetermined categories, the authors grouped the answers under themes which emerged from the answers. As new themes emerged, previous responses were reviewed to ensure that all relevant themes were captured in all of the answers (Miles and Huberman, 1994). To ensure inter-rater reliability, each co-author separately doublechecked the relevance of the initial coding and, if necessary, made counter-suggestions. One of the bilingual authors then translated the data from French to English. The second bilingual author cross-checked the translation and if necessary provided an alternative translation, which was then validated by the first author.

We first present the female sample and then the male sample. The female respondents represented a range of industries, functional areas, organisational levels and ages. Industries came primarily from the following sectors: construction, banking, higher education, communication and marketing, with the energy sector well represented. The most represented age brackets in order of prevalence were 41-50 years (43\%), 31-40 years (26\%), 51-60 years (18\%), under 30 years (12\%). The female respondents had an average of two children. The most represented level of studies was the 5 year postgraduate degree (77\%), $93 \%$ of the female respondents were working, and $86 \%$ were managers (“cadre” in French). The distribution of number of years of professional activity among the sample was 11-20 years (38\%), 21-30 years (30\%), and 10 years and under (18\%). Industries within the male sample were more homogeneous than among the female, as three men worked in higher education, one in construction, and one in community service. The most represented age brackets in 
order of prevalence were 51-63 years (60\%), 41-50 years (20\%), and 31-40 years (20\%) making the male sample more mature than the female. All five men had children: three men had two, one had three, and one had one child. The educational level of the male sample was higher than that of the female sample as three men had either an MBA or a doctoral degree. While four men had manager status, one had employee status. The number of years of professional activity of the men varied from 12 to 43 years.

\section{Managers' perceptions of what a female career is}

$43 \%$ of the female and male respondents associated a female career with "work-life balance choices". For $18 \%$ a female career is "fulfilment and a personal project built over time" whereas $15 \%$ stated that there was "no difference from a male career". $11 \%$ of respondents considered a female career to be a "battle, or [to have] more obstacles than a man's". The remaining $6 \%$ addressed different issues. $2 \%$ of the female respondents answered "I do not know" and 5\% of the female respondents did not answer the question at all. All five male managers answered the question. Table 2 presents example verbatim answers associated with key characteristics, by order of prevalence.

\section{Managers' perceptions of their careers}

\begin{tabular}{|l|l|}
\hline Characteristics & What is a female career? \\
\hline $\begin{array}{l}\text { Work-life balance } \\
\text { choices (43\%) }\end{array}$ & $\begin{array}{l}\text { "It is great willingness to conciliate private-professional life. It is a constant calling } \\
\text { into question, to know which goals one wants to achieve professionally and in what } \\
\text { time frame." (F: } 39 \text { yrs, } 2 \text { children) } \\
\text { "A constant adaptation between personal desire, following the career pathway of the } \\
\text { husband and educating the children. I alternated between periods of training and } \\
\text { professional experience." (F: } 64 \text { yrs, } 2 \text { children) } \\
\text { "Knowing how to move on both fronts: family and professional." (M: } 56 \text { yrs, } 1 \text { child) } \\
\text { "If I understand well, I seem to have a female career: changing cities to join my wife in } \\
\text { Nancy, } 1 \text { year parental leave, juggling time to pick up the children at school, etc. but } \\
\text { they are life choices [I don't have a managerial status]." (M: } 37 \text { yrs, 3 children) }\end{array}$ \\
\hline $\begin{array}{l}\text { Fulfilment and a } \\
\text { personal career } \\
\text { built over time } \\
\text { (18\%) }\end{array}$ & $\begin{array}{l}\text { "A chievement and self-fulfilment in a professional career." (F: } 21 \text { yrs, no children) mature career. A female career is built over time with patience, } \\
\text { determination and a bit of abnegation...with often the necessity of taking secondary } \\
\text { pathways, climbing over mountains, which makes women's careers all the more rich. } \\
\text { The taste for adventure and a little bit of 'provoc[ation]'." (F: } 47 \text { yrs, more than } 3\end{array}$ \\
\hline
\end{tabular}




\begin{tabular}{|c|c|}
\hline & children) \\
\hline $\begin{array}{l}\text { No different to a } \\
\text { male career } \\
(15 \%)\end{array}$ & $\begin{array}{l}\text { "There is no such thing as a female career. It is up to each person to find his/her } \\
\text { definition of career and success." (F: } 54 \text { yrs, } 1 \text { child) } \\
\text { "Hardly any difference, even less today." (M: } 36 \text { yrs, } 2 \text { children) }\end{array}$ \\
\hline $\begin{array}{l}\text { A battle, more } \\
\text { obstacles for } \\
\text { women }(\mathbf{1 1 \% )}\end{array}$ & $\begin{array}{l}\text { "I don't know. I wouldn't know either how to answer for men. I only know that, for } \\
\text { women to make a career, it is harder to climb, to be paid as much as men for an } \\
\text { equivalent position. You get tired and stop wanting to fight to climb." (F: } 54 \text { yrs, } 3 \\
\text { children) } \\
\text { "Today, it is an everyday battle, to show that we can do as much as a man, or even } \\
\text { more. To be incredibly strong in character and question oneself in order to advance. To } \\
\text { not doubt one's value and capacities. To be able to face adversity, especially macho } \\
\text { statements, to leave aside demeaning remarks." (F: } 28 \text { yrs, } 0 \text { children) } \\
\text { "The same as a male career with perhaps a little more effort." (M: } 63 \text { yrs, } 2 \text { children) }\end{array}$ \\
\hline \multicolumn{2}{|c|}{$\begin{array}{l}\text { "It's undeniable that a woman's career today is different from that of a man's. But in my opinion there should } \\
\text { not be any difference in career between the two sexes (apart from 'physiological' differences such as those } \\
\text { related to pregnancy, etc.)." (F: } 41 \text { yrs, } 2 \text { children) }\end{array}$} \\
\hline \multicolumn{2}{|l|}{ Non-linear } \\
\hline $\begin{array}{l}\text { "V } \\
\text { us }\end{array}$ & of not being obligated to engage along a straight career pa \\
\hline
\end{tabular}

How do female and male managers perceive their career pathway? The gendered career theory will be useful for our analysis. The majority of the female (86\%) and three out of the five male (60\%) respondents engaged in explanations of what entails a female career. For these respondents, women's careers progress differently than men’s. Perceptions of gendered careers are grounded in the belief that women and men, as members of distinct social categories in the workplace and job market, experience different challenges along the career pathway which can be explained, as mentioned in the literature review, by developmental differences, and societal and cultural factors (O’Neil and Bilimoria, 2005). The search for work-life balance, fulfilment, and building a personal career over time, while overcoming obstacles and even battling, emerge as typical characteristics of female careers.

In the eyes of a significant number of respondents in the study, both female and male, career and concern for work-life balance are clearly intertwined. The search for work-life balance requires flexibility on the part of women, to adapt to the numerous constraints perceived. 
Moreover, some aspects of female career development appear to be chosen, others imposed by family obligations or perceptions of women's role in society. Does this outcome reveal a French specificity? Apparently not: as Dyke and Murphy (2006) point out in a Canadian study, women differ from men in their definition of success, placing greater importance on work-life balance than material gains. Similar results were found in a study of managerial women in four countries (Bulgaria, Canada, Norway, and Singapore), with women across the countries sharing similar career priority patterns combining family and career (Burke, 2000). Is a French female career characterised by the requirement to juggle many external factors in order to succeed, and as being inseparable from family obligations? Does this requirement reflect the definition of career success in France for female managers? The French context reveals certain characteristics. With almost two children per woman, the French birth rate is one of the highest in Europe (Davie and Magali-Mazuy, 2010; INSEE, 2016). Many French children grow up with both parents working as $60 \%$ of French women work (European Commission, 2013a). The French female employment rate is therefore slightly above the EU27 average (58.6\%), but lagging behind countries like Sweden with $71.8 \%$ of women in the workforce (European Commission, 2013b). The French family policy, consisting of childcare facilities, tax allowances, and family benefits, including both paid maternity and paternity leaves, plays a crucial role (French Diplomacy, 2013). From these observations, one can conclude that, in France, having children is part of the culture, and managing both professional and family lives is on the daily agenda.

Beyond associating work-life balance with a female career, a significant number of female respondents pointed to personal fulfilment and a career built over time as key characteristics. Although none of the male respondents used these terms, the only male non-manager observed that he most likely had a female career as he had followed his wife, taken a one-year parental leave, and juggled working hours with childcare responsibilities, which for him were 
life choices. This finding seems to resonate with the work of Dyke and Murphy (2006) which questions how women and men define success, and with the work of numerous researchers, starting with Levinson and Levinson (1994) who investigated gender differences towards time and with respect to life stages. Interestingly, the perception of the female manager in Table 2 who saw the female career as a privilege, and a benefit which should be extended to men, echoed the perception of the only male non-manager in the sample, who spoke of his femalelike career as a life choice.

A final key characteristic of female careers emerging from the study was the presence of multiple obstacles, including care responsibilities, sometimes assumed alone, and following one's spouse. While one woman went as far as to associate the female career to a battle, one male respondent mildly suggested that women perhaps put more effort into their careers than men. As previously mentioned, in France, women's careers are negatively influenced by the number of children they have, whereas the opposite is the case for men (Belghiti-Mahut and Landrieux-Kartochian, 2008; Ferro-Vallé, 2009). Laufer and Pochic (2004) also point out the weight of the dominant dual-career model of female managers. This situation also has an impact on the way women negotiate with their partner or husband. In many cases, it is the woman who is in charge of family obligations and decisions (Ferro-Vallé, 2009). As Laufer (2005) demonstrated, the choices made within couples are often in favour of the man's career, and in detriment to the woman's career. Within the “male model of working”, long working hours, physical presence (“le présentéisme” in French), and geographical mobility are detrimental to female career development. Finally, we may question to what extent the French context may be considered "special", as the discussion shows similar results could be expected across Western countries.

\section{Perceptions of genderless careers}


For a minority of the female respondents (14\%) and two of the five male respondents (40\%), there is no such thing as a female career. Such a perspective raises the question of the necessity of a gender-distinct approach to careers. Perceptions of genderless careers maintain that, as women and men are equally competent, and have equal opportunities to pursue a professional career, there is no need to adopt a distinct gender approach to careers. The "no different to a male career” category captures these perceptions. For these managers, career advancement is not a question of gender but above all of individual competences and career aspirations, with shared female/male work-life balance expectations. It is significant, despite the small sample of men, to note that two out of the five male managers espoused the genderless career, for different reasons. One stated simply that there were few differences today between male and female careers. The other observed the need to seek balance between professional/private/family pathways, with the support of one's partner, which for him was a goal shared by women and men alike. This last remark points to the work-life balance characteristic previously presented as commonly associated with female careers. Voiced by a male, it resonates with the ABC Kaleidoscope Career model (Mainiero and Sullivan, 2006) which integrates work-life balance as a major concern for today's managers, both male and female. This suggests that individuals may express a concern for work-life balance at a certain stage of their career, and organisations should be able to respond to this expectation, whether expressed by a female or a male.

\section{Perceptions of the existence of a glass ceiling}

Having investigated the managers' perceptions of a female career, we now investigate the extent to which the managers see a glass ceiling in their organisation. The following results emerged regarding the idea of a glass ceiling as a career obstacle: $60 \%$ of the female respondents stated that there was a glass ceiling in their organisation, 29\% replied "no" and $11 \%$ did not answer the question. Four out of the five men (80\%) said that was there was no 
glass ceiling in their company; one man differed, affirming "yes there is one”. Table 3 presents verbatim examples from female and male respondents.

\section{Managers' perceptions of the existence of a glass ceiling}

\begin{tabular}{|l|l|}
\hline Answer & $\begin{array}{l}\text { Do you think a “glass ceiling” exists in the organisation you work for? } \\
\text { Please explain your answer. }\end{array}$ \\
\hline Yes & $\begin{array}{l}\text { "For a long time I was managed by a boss who 'protected' me so that I could balance } \\
\text { my professional and private lives, which unconsciously created barriers for me." (F: } 43 \\
\text { yrs, } 3 \text { children) } \\
\text { "There are many types of discrimination in companies: social milieu, graduate school, } \\
\text { home address, personal wealth, elitist club membership, family of origin, marital } \\
\text { status, etc." (M: } 56 \text { yrs, } 1 \text { child) }\end{array}$ \\
\hline No & $\begin{array}{l}\text { "I still may be concerned by self-censorship but not by a glass ceiling either for myself } \\
\text { or for my collaborators because I prefer self-determination." (F: 42 yrs, } 3 \text { children) } \\
\text { "In the Group today, a woman heads a division, proving that when there are equal } \\
\text { competencies both women and men can achieve all levels of responsibilities." (M: } 63 \\
\text { yrs, } 2 \text { children) }\end{array}$ \\
\hline
\end{tabular}

In contrast to the male respondents, the majority of the women perceived the existence of a glass ceiling, which confirms previous research findings (Laufer, 2005; Belghiti-Mahut and Landrieux-Kartochian, 2008). Similar results have been found in a UK survey, in which 73\% of female managers believed there was a glass ceiling, compared to $38 \%$ of men (Snowdon, 2011). When asked to explain, the female respondents in our survey pointed to such factors as the existence of male-dominated organisational cultures with hidden codes to success, women having to work twice as hard as men to prove their worth, and traditional role distribution which favours women in social assistant roles and men as decision makers. Only one out of the five men reported the existence of a glass ceiling in his organisation, which he saw as effecting a broad range of employees: those not belonging to the right clubs, networks or income brackets, and late comers to the business. However, he made no particular mention of women. In summary, this often covert barrier to women's career progression is more visible to women than it is to men. Women may also internalise the existence and persistence of the glass ceiling as this metaphor is largely attributed to women in the press and mass media. 
Accordingly, women and men internalise expectations of their professional and social roles. Cultural pressures also condition their perceptions.

\section{The power of career images: traditional versus contemporary images}

What can a chosen career image reveal about how female and male managers perceive their career pathway? The participants were asked to choose from five suggested career images, the one which best corresponded to their career. In the case that none of the images fit with their way of picturing their career, they were invited to draw their own image and provide an explanation for it.

The majority of the female (76\%) and the male (80\%) respondents chose an image from among those presented. It is, however, significant to note that the remaining respondents did not, preferring either a combination of the images, or different images, or explanations of personal approaches to career development. With only two respondents not answering the question, clearly using images to picture one's career was stimulating. Table 4 below presents the results in order of prevalence among the respondents.

\section{Images corresponding to own career}

\begin{tabular}{|c|c|c|c|c|}
\hline Image & $\begin{array}{c}\text { Number of female } \\
\text { respondents }\end{array}$ & $\mathbf{\%}$ & $\begin{array}{c}\text { Number of male } \\
\text { respondents }\end{array}$ & $\mathbf{\%}$ \\
\hline Mountain & 22 & 23.66 & 1 & 20 \\
\hline Own images & 22 & 23.66 & 1 & 20 \\
\hline Labyrinth & 18 & 19.35 & 2 & 40 \\
\hline Vertical ladder & 16 & 17.20 & - & - \\
\hline Roller coaster & 10 & 10.75 & 1 & 20 \\
\hline Horizontal ladder & 3 & 3.23 & - & - \\
\hline Blank answer & 2 & 2.15 & - & - \\
\hline Total & $\mathbf{9 3}$ & $\mathbf{1 0 0 \%}$ & $\mathbf{5}$ & $\mathbf{1 0 0 \%}$ \\
\hline
\end{tabular}


The earlier literature review led us to portray such career images as a mountain and a vertical ladder as traditional, and others such as a horizontal ladder, a roller coaster, and a labyrinth as contemporary. There was a rather even distribution among the images chosen by both the women and the men with the mountain being ranked first by women, followed by the labyrinth, the vertical ladder, and the roller coaster. Male respondents chose first the labyrinth, followed equally by the mountain and the roller coaster. Some of the respondents drew or described complex schematic representations of their own career development. While nine women chose to draw their own picture, nine others described their career in their own words. The following "own images" were used: a combination of two ladders, three lines, a crossroads, a nearly straight line, a staircase, a spiral, various organic images, jumping over traps and avoiding obstacles, and a dream. Several women drew a combination of the vertical and horizontal ladders with different stories. A number of the personal images and written briefs seemed to be related to the various forms of careers found in the research, some belonging to female career models and others to genderless models. The upward spiral drawn by one woman can be associated with the spiral career of Brousseau et al. (1996) as well as the female career model elaborated by Rapoport and Rapoport (1980), who proposed a triple (occupational, family and leisure) helix image to capture transitions in life which mark the career choices of women and convey dynamics such as critical impacts of events in the developmental process and the balancing of steady states between transitions. Similar to the metaphor of a career as a cycle (Inkson, 2004), another woman wrote "self-decided career cycles”. Further, three women drew more organic images, such as a flower, a tree, or a treelined path with the trees becoming smaller as the path continued into the distance. Orderly organic-inspired images can be likened to Baruch’s (2004) gardening metaphor for a career. Tree drawings can be associated with the female career model of Larwood and Gutek (1987), who depicted a tree with branches to symbolise combinations of alternatives leading to 
potentially different outcomes. One female respondent who chose a tree underlined how much more energy and organisation a woman's career requires than a man's. Another woman depicted a crossroads with seven possible roads and a dot in the middle indicating "me”, raising the question "at the crossroads: which way to go for a satisfying professional life?" This could be likened to Iellatchitch et al.'s (2003) chronically flexible career model. The respondents' perceptions of a female career and the images chosen to describe their own careers are rather aligned. For example, one female respondent described her career as a “path with obstacles” while choosing the labyrinth image.

With regards to age, level of education, and number of years of work, the respondents in our sample could be considered as having a certain degree of experience with the notion of career. Across the different age categories, and regardless of the number of children they had, women chose both traditional images of careers such as the mountain and vertical ladder, and more contemporary images such as the labyrinth. It is interesting to note that the labyrinth image, developed by Eagly and Carli (2007), and aimed at better capturing characteristics of female careers, was also chosen by men, which indicates that this image is not strictly applicable to women's careers, thus is not a gender-distinct metaphor. It is also significant to note that, when choosing traditional images of a mountain or a vertical ladder, the women commonly added contemporary career features identified in the literature review such as, for the mountain image, the need to take the necessary time to, as one woman summed up, "advancepause-advance" in order to "seek family and professional life balance" when moving upwards. As outlined in the review of the career literature, early career models resulted from studies on men (Super, 1957; Levinson, 1978). Interestingly, none of the men chose the more traditional hierarchical career image of the vertical ladder. However, nearly $20 \%$ of the women did, suggesting that a linear career is possible from a woman's viewpoint. 
The approach taken in this paper is innovative as images discussed in the literature are used for a field study. Therefore, we can see the potentiality of advanced or even new observations and implications (Cornelissen, 2002) to bring forward research on careers using the medium of images. Such an agenda is in line with Inkson's (2004) observation that metaphors have the potential to advance thinking about careers, beyond the framing of familiar metaphors, and provide a broader and more inclusive understanding of career phenomena. This study contributes to the career literature by providing insights into how female and male managers perceive a female career. The empirical results confirm the multiplicity of a French female manager's career path (Laufer and Pochic, 2004) and work-life balance as a major preoccupation for French managers.

As outlined above there are several contributions as well as limitations inherent in this study. While using images to investigate perceptions of career barriers and pathways is innovative, it is evident that proposing a set of images to choose from may introduce a bias. The manager sample was composed largely of mature women and men, well-placed to look back on their career pathways and the existence of career barriers. Owing to the nature of the female networking event itself, men were significantly less numerous than women. Yet, interestingly, despite this, significant convergences and divergences were identified in the perceptions and interpretations of female careers provided by the female and male respondents. Next, the decision to take advantage of a women's networking event to survey attendees could have had an impact on the results if we assume that women attending a networking event are a priori sensitive to progressing on a professional level and that the few men attending, by their very presence, may be more open-minded than the average male. Finally, the French network in question offers the advantage of polling a very diverse population of women, from a variety of organisations and social situations representative of the more regional, as opposed to dense metropolitan, business landscape of France. 


\section{Conclusion}

The purpose of this study was to better understand how women and men perceive female careers, and to gain a greater understanding of how managers picture their own careers. The study reveals that female and male careers have multiple forms. Our empirical results also reveal that there are convergences and divergences between how female and male managers perceive female careers. Women associate both personal fulfilment and the presence of greater obstacles with female careers. The career image choices made by the participants indicate that both female and male managers are particularly concerned about work-life balance while managing their careers.

Further, connecting individual perceptions of female careers and career images allows us to provide a more rounded understanding of how people perceive their own careers. The results confirm the benefits of using images to reveal the complexities of managers' careers, and especially those of women. Our research indicates that communicating about one's career through images appeals to managers. Images provide a rich medium for reflecting and discussing layers of unconsciousness, and for solution-finding that is useful for both individuals and organisations. Women themselves may be encouraged through images to picture or draw, and subsequently take ownership of, their careers in order to take a proactive approach and move on. For Eagly and Carli (2007), metaphors matter because they are part of the storytelling that can compel change. Our study links the theoretical debate of female career obstacles, which mostly refers to a structural analysis (macro/meso level), to an empirical approach focusing on individual perceptions. This perspective leads to further research questions about the way individual perceptions and the institutional context influence each other.

Further studies could use one-to-one interviews with a female and a male sample from the same organisation with operations in different European contexts, so as to be able to better 
capture organisational and national influences on individual perceptions. Further research could also use a broader range of images from gender-distinct and genderless career models, and propose them to a larger sample of both male and female managers. Qualitative interviews would offer the managers the opportunity to explain their interpretations of the images, and their perceptions of their own careers. The resulting narratives would provide a more in-depth understanding of individual career paths, be they those of women or men. Such an agenda would contribute to the need for documenting the experiences of women and men so as to progressively guide societal constructions of careers closer to individual realities.

\section{Bibliography}

Arthur, M.B., Hall, T.D., \& Lawrence, B.S. (Eds.). (1989), Handbook of career theory, New York, NY: Cambridge University Press.

Baruch, Y. (2003), Career systems in transition: A normative model for career practices. Personnel Review, 32(2), pp. 231-251.

Baruch, Y. (2004), Managing careers: theory and practice, Essex, UK: Pearson Education Limited.

Belghiti-Mahut, S. (2004), Les déterminants de l'avancement hiérarchique des femmes cadres [Determinants of hierarchical advancement of women executives]. Revue Française de Gestion, 4(151), pp. 145-160.

Belghiti-Mahut, S., \& Landrieux-Kartochian, S. (2008), Le plafond de verre, encore et toujours [The glass ceiling, again and again]. In A. Cornet, J. Laufer \& S. Belghiti-Mahut (Eds.), Genre et GRH. Les défis de l'égalité hommes-femmes [Gender and HRM: The challenges of equality between women and men] (pp. 105-124). Paris: Vuibert.

Bozionelos, N. (2003), Career perceptions and the psychological contract in organizational downsizing. In M.A. Rahim, R.T. Golembiewski \& K.D. Mackenzie (Eds.), Current topics in management (pp. 295-312). New Brunswick, NJ: Transaction Publishers.

Brousseau, K.R., Driver, M.J., Eneroth, K., \& Larsson, R. (1996), Career pandemonium: Realigning organisations and individuals. Academy of Management Executive, 10(4), pp. 5266.

Burke, R.J. (2000), Career priority patterns among managerial women: A study of four countries. Psychological Reports, 86(3), pp. 1264-1266.

Cadin, L., Bender, A-F., Saint-Giniez, V., \& Pringle, J. (2000), Carrières nomades et contextes nationaux [Nomad careers and national contexts]. Revue de gestion des ressources humaines, Vol. 3 No. 37, pp. 76-96. 
Clark, F.A. (1996), Total career management: Strategies for creating management careers. Maidenhead: McGraw Hill.

Cornelissen, J.P. (2002), On the 'organizational identity' metaphor. British Journal of Management, 13(3), pp. 259-268.

Davie, E., \& Magali-Mazuy, M. (2010), Fécondité et niveau d'études des femmes en France à partir des enquêtes annuelles de recensement [Fertility and women's level of education in France from annual census surveys]. Population-F, 65(3), pp. 475-512.

Dyke, L.S., \& Murphy, S.A. (2006), How we define success: A qualitative study of what matters most to women and men. Sex Roles, 55(5), pp. 357-371.

Eagly, A., \& Carli, L. (2007), Women and the labyrinth of leadership. Harvard Business Review, 85(9), pp. 63-71.

Eikhof, D. (2012), A double-edged sword: 21st century workplace trends and gender equality. Gender in Management, 27(1), pp. 7-22.

European Commission. (2013a), The current situation of gender equality in France. Country profile. Retrieved from http://ec.europa.eu/justice/genderequality/files/epo_campaign/131203_country-profile_france.pdf (accessed 24 February 2017).

European Commission. (2013b), The current situation of gender equality in Sweden. Country profile. Retrieved from http://ec.europa.eu/justice/genderequality/files/epo_campaign/131006_country-profile_sweden.pdf (accessed 24 February 2017).

Ferro-Vallé, E. (2009), Egalité professionnelle entre les femmes et les hommes [Professional equality between women and men]. La Plaine-Saint Dénis: AFNOR éditions.

French Diplomacy (2013), With 2.01 children per woman, France has one of the highest fertility rates in Europe. Retrieved from http://www.diplomatie.gouv.fr/en/french-foreignpolicy/economic-diplomacy-foreign-trade/facts-about-france/one-figure-one-fact/article/2-01the-average-number-of (accessed 7 January 2017).

Goldberg, L. R. (1990). An alternative “description of personality”: The big-five factor structure. Journal of Personality and Social Psychology, 59(6), pp. 1216-1229.

Hakim, C. (2000), Work-lifestyle choices in the $21^{\text {st }}$ century. Oxford: Oxford University Press.

Hall, D., \& Mirvis, P. (1996), The new protean career: Psychological success and the path with a heart. In D. Hall (Ed.), The career is dead - long live the career (pp. 15-45). San Francisco: Jossey-Bass.

Herman, C., Lewis, S., \& Humbert, A-L. (2013), Women scientists and engineers in European countries: Putting motherhood under the microscope. Gender, Work and Organization, 20(5), 467-478.

Hewlett, S.A., \& Luce, C.B. (2005), Off-ramps and on-ramps: Keeping talented women on the road to success. Harvard Business Review. Retrieved from https://hbr.org/2005/03/offramps-and-on-ramps-keeping-talented-women-on-the-road-to-success (accessed 14 January 2017)

Iellatchitch, A., Mayrhofer, W. \& Meyer, M. (2003), Career fields: A small step towards a grand career theory? International Journal of Human Resource Management, 14(5), 728-750.

Inkson, K. (2004), Images of career: Nine key metaphors. Journal of Vocational Behavior, 65(1), 96-101. 
Inkson, K., \& Amundson, N.E. (2002), Career metaphors and their application in theory and counseling practice. Journal of Employment Counseling, 39(3), pp. 98-108.

INSEE. (2016), Fécondité [Birthrate]. Retrieved from https://www.insee.fr/fr/statistiques/1892259?sommaire=1912926 (accessed 9 January 2017).

Kram, K.E., Wasserman, I.C., \& Yip, J. (2012), Metaphors of identity and professional practice. Learning from the scholar-practitioner. Journal of Applied Behavioral Science, 48(3), 304-341.

Landrieux-Kartochian, S. (2003), Au-delà du plafond de verre? L'introduction de la dimension genre dans les politiques de gestion des ressources humaines [Beyond the glass ceiling? The introduction of the gender dimension in human resource management policies]. Les Cahiers du CERGOR nº 03/01, Université Paris 1 Panthéon Sorbonne, January.

Larwood, L., \& Gutek, B. (1987), Working towards a theory of women's career development. In B. Gutek \& L. Larwood (Eds.), Women's career development. Newbury Park, CA: Sage.

Laufer, J. (2004), Femmes et carrières: La question du plafond de verre [Women and careers: The glass ceiling issue]. Revue Française de Gestion, 4(151), pp. 117-127.

Laufer, J. (2005), La construction du plafond de verre: Le cas des femmes cadres à potentiel [The construction of the glass ceiling: The case of executive women managers]. Travail et Emploi, 102, april-june, pp. 31-44.

Laufer, J., \& Pochic, S. (2004), Carrières au féminin et au masculin [Feminine and masculine careers]. In A. Karvar \& L. Roubain (Eds.), Les cadres au travail. Les nouvelles règles du jeu [Executives at work: The new rules of the game] (pp. 147-168). Paris: La Découverte.

Levinson, D.J. (1978), The seasons of a man's life. New York, NY: Knopf.

Levinson, D.J., \& Levinson, J.D. (1994), The seasons of a woman's life. New York, NY: Knopf.

Mainiero, L., \& Sullivan, S. (2006), The opt-out revolt: Why people are leaving companies to create kaleidoscope careers. Mountain View, CA: Davies-Black.

Masterson, C., \& Hoobler, J. (2015), Care and career: A family identity-based typology of dual-earner couples. Journal of Organizational Behavior, 36(15), pp. 75-93.

Mayrhofer, W., Meyer, M., Schiffinger, M., \& Schmidt, A. (2008), The influence of family responsibilities, career fields and gender on career success: An empirical study. Journal of Managerial Psychology, 23(3), pp. 292-323.

Miles, M., \& Huberman, M. (1994), Qualitative data analysis: An expanded sourcebook (2 ${ }^{\text {nd }}$ ed.). Thousand Oaks, CA: Sage.

Morgan, B., \& Foster, V. (1999), Career counselling for reentry dual career women: A cognitive developmental approach. Journal of Career Development, 26(2), pp. 125-136.

Naschberger, C., Quental, C., \& Legrand C. (2012), Le parcours de carrière des femmes cadres: Pourquoi est-il si compliqué et comment le faciliter? [The career path of women managers: Why is it so complicated and how can we facilitate it?] Gestion: Revue Internationale de Gestion, 37(3), pp.43-50.

Naschberger, C., Quental, C., \& Legrand, C. (2017), The leaky leadership pipeline in France. A study of career levers and barriers to foster women's leadership development. In C.M. Cunningham \& H.M. Crandall (Eds.), Gender, communication, and the leadership gap (pp. 
151-169). Women and Leadership Book Series, Vol. 6, Information Age Publishing, Charlotte: North Carolina.

Nicholson, N. (1996), The new context of careers. In Warr, P. (Ed.), Psychology at work (4 ${ }^{\text {th }}$ ed.) Penguin, Harmondsmith, pp. 161-187.

O’Neil, D., \& Bilimoria, D. (2005, June), Women and careers. A critical perspective on the theory and practice of women in organizations. Paper presented at the $21^{\text {st }}$ EGOS Colloquium, Berlin.

O’Neil, D., Hopkins, M., \& Bilimoria, D. (2005), Women's career development phases: Idealism, endurance and reinvention. Career Development International, 10(3), pp. 168-192.

O’Neil, D., Hopkins, M., \& Bilimoria, D. (2008), Women's careers at the start of the $21^{\text {st }}$ century: Patterns and paradoxes. Journal of Business Ethics, 80(4), pp. 727-743.

Peterson, R.A., \& Anand, N. (2002), How chaotic careers create orderly fields. In M.A. Peiperl, M. Arthur, R. Goffee \& N. Anand (Eds), Career creativity: explorations in the remaking of work. (pp. 257-279), Oxford : Oxford University Press.

Pralong, J. (2009), Projet de mobilité interne et carrière organisationnelle: d'un nouveau modèle du projet à une redéfinition de la carrière [Internal mobility project and organizational career: A new model for career redefinition]. Revue multidisciplinaire sur l'emploi, le syndicalisme et le travail, 4(1), pp. 3-26.

Rapoport, R., \& Rapoport, R.N. (1980), Balancing work, family and leisure: A triple helix model. In C.B. Derr (Ed.), Work, family and the career (pp. 318-328). New York: Praeger Publishing.

Rosenbaum, J. (1979), Tournament mobility: Career patterns in a corporation. Administrative Science Quarterly, 24(2), pp. 221-241.

Rousseau, D. (1996), Changing the deal while keeping the people. Academy of Management Executive, 10(1), pp. 50-59.

Scambor, E., Wojnicka, K., \& Bergmann, N. (2013), The role of men in gender equality. European Strategies \& Insights, European Commission, Luxembourg, 332p. Retrieved from http://ec.europa.eu/justice/gender-

equality/files/gender_pay_gap/130424_final_report_role_of_men_en.pdf（accessed 14 February 2017).

Snowdon, G. (2011), Women still face a glass ceiling. Retrieved from https://www.theguardian.com/society/2011/feb/21/women-glass-ceiling-still-exists-top-jobs (accessed 14 January 2017).

Solomon, B.C., \& Jackson, J.J. (2014), The long reach of one's spouse: Spouses’ personality influences occupational success. Psychological Science, 25(12), pp. 2189-2198.

Super, D.E. (1957), The psychology of careers. New York, NY: Harper \& Row.

Vinquant, J.P (2017), Vers l'égalité réelle entre les femmes et les hommes. [Towards real equality between women and men] Retrieved from http://www.familles-enfancedroitsdesfemmes.gouv.fr/wp-content/uploads/2017/03/27999-DICOM-Brochure-egalite-FH2017-v4_bd.pdf (accessed 23 February 2017).

White, B. (1995), The career development of successful women. Women in Management Review, 10(3), pp. 4-15. 
White, B. (2000), Lessons from the careers of successful women. In M.J. Davidson \& R.J. Burke (Eds.), Women in management, current research issues (Vol II, pp. 164-176). Thousand Oaks, CA: Sage Publications.

Williams, J. (2000), Unbending gender: Why family and work conflict and what to do about it. New York, NY: Oxford University Press.

Yarnall, J. (2008), Strategic career management: Developing your talent. Oxford, UK: Elsevier. 
Appendix 1: Career Images: Selection of images as appeared on slide presentation and to which respondents referred to in the questionnaire.

Which image best corresponds to your career?
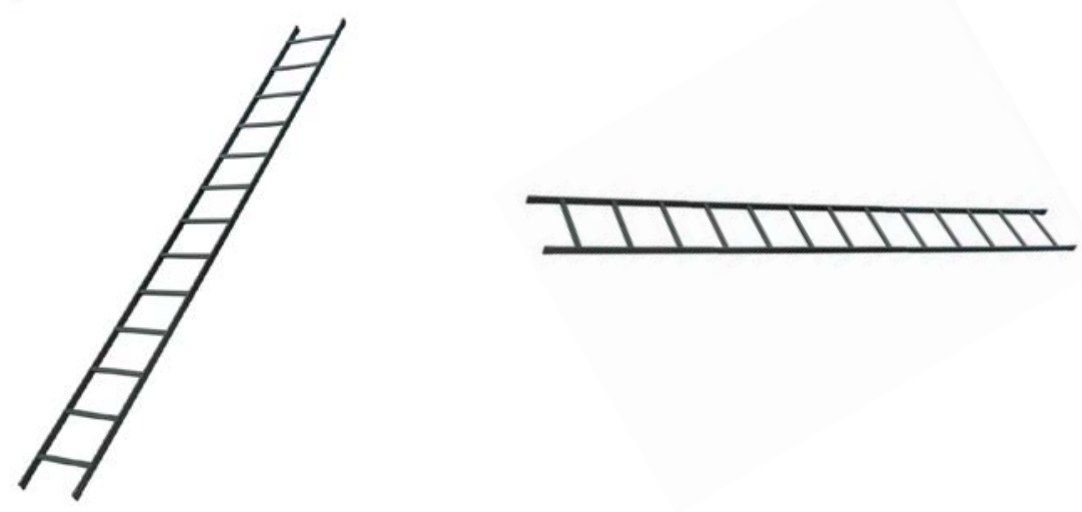

A. Vertical ladder

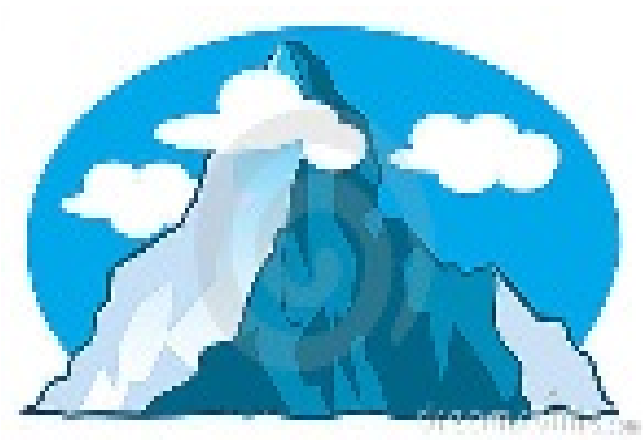

C. Mountain

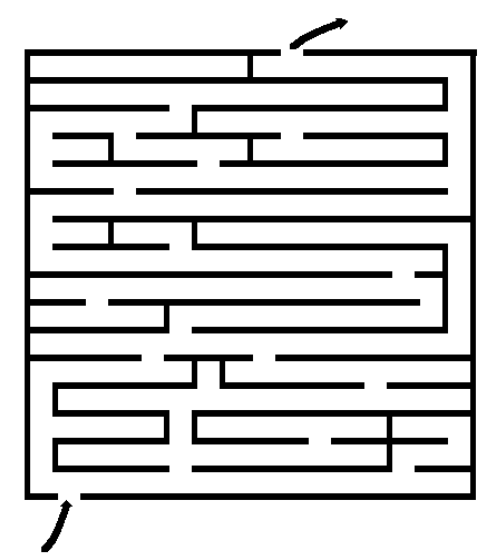

D. Labyrinth
B. Horizontal ladder

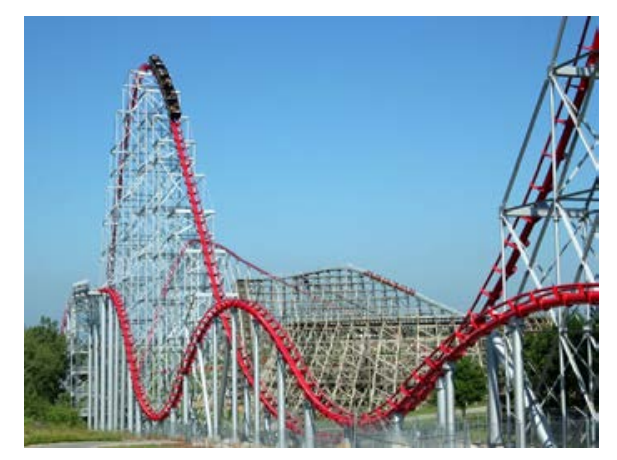

D. Roller coaster

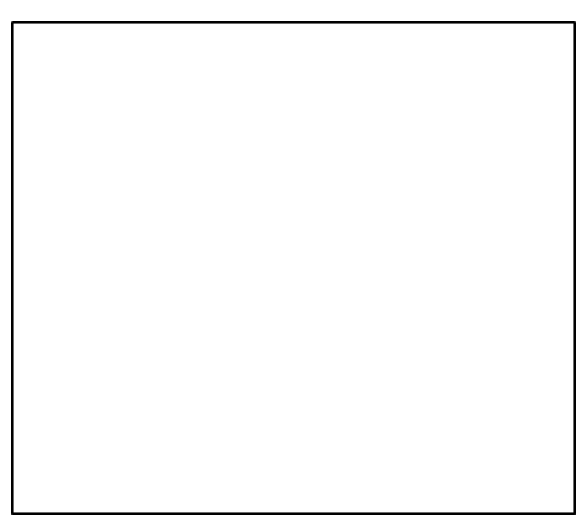

E. Draw your own picture or describe in your own words 